\title{
Blackpool central area coast protection scheme, UK
}

1 Lee Cunningham MEng, PhD, CEng, MICE, MIStructE Senior Engineer, Blackpool Council, Blackpool, UK

a Gareth Robertshaw MEng, CEng, MICE

Principal Coastal Engineer, Halcrow Group Ltd, Handforth, UK
3 Mike Pomfret MSc, CEng, MICE, CEnv, MCIArb Consultancy Manager, Blackpool Council, Blackpool, UK
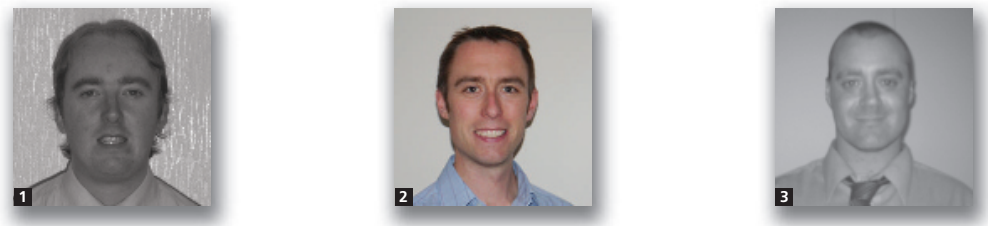

The Blackpool central area coast protection scheme is the largest single UK coastal defence project completed in the past 10 years. The scheme is situated in a key location of this nationally important tourist destination. It has successfully addressed the dual aims of delivering significantly improved coastal defences and high-quality public realm as an integral part of a regeneration masterplan. This paper discusses the partnering approach adopted throughout the design and construction of the scheme together with identifying the key challenges that were addressed, enabling innovative engineering and construction solutions to be adopted which delivered considerable benefits in terms of aesthetic quality, constructability and durability.

\section{Introduction}

Tourism is Blackpool's raison d'être. It is the UK's most popular coastal holiday resort (Figure 1), receiving 14.5 million visitors per year and generating $£ 1$ billion for the local economy (http:// www.visitblackpool.com). The town has enjoyed a special status within popular culture for well over a century, with tourists coming from all over the British Isles. The central sea front, often referred to as the Golden Mile is known and loved by millions. Delivering new coastal defences to this core area has presented both a challenge and an opportunity.

The Blackpool central area coast protection scheme has replaced the existing coastal defence along a $3.5 \mathrm{~km}$ stretch of coastline between the historic North and South Piers with new structures designed to enhance the standard of protection against coastal flooding and erosion. This section of frontage is the most heavily used for leisure and recreation by tourists and local residents.

The timing of the works was opportune in that the changes would be undertaken in parallel to a period of major regeneration in the town. This provided a unique opportunity for the creation of high-quality, highly aesthetic public realm for the sea front thus meeting one of the key aims of the Blackpool Masterplan (EDAW and Jerde, 2003).
Recognising the challenge of meeting the twin objectives from the outset, Blackpool Council set up a multi-disciplinary and interactive team to deliver the scheme design. The team comprised the council's in-house engineering service, consulting engineer (Halcrow Group Ltd), landscape architects (EDAW and LDA Design) and the contractor (Birse Coastal) through an early contractor involvement (ECI) arragement.

The team identified a number of key challenges which required best practice engineering solutions and innovation in both design and construction. This paper discusses each of the following topics in further detail.

(a) Developing a defence shape that provides enhanced protection from overtopping while maintaining the important vistas.

(b) Reconnecting the town to its beach, a key aspiration of the Council and local community to improve accessibility to the beach and promenade.

(c) Linking the new sea front to public realm and creating new areas of open space.

(d) Improving durability of materials to ensure that the project would look as good in the future as the day it was constructed. 


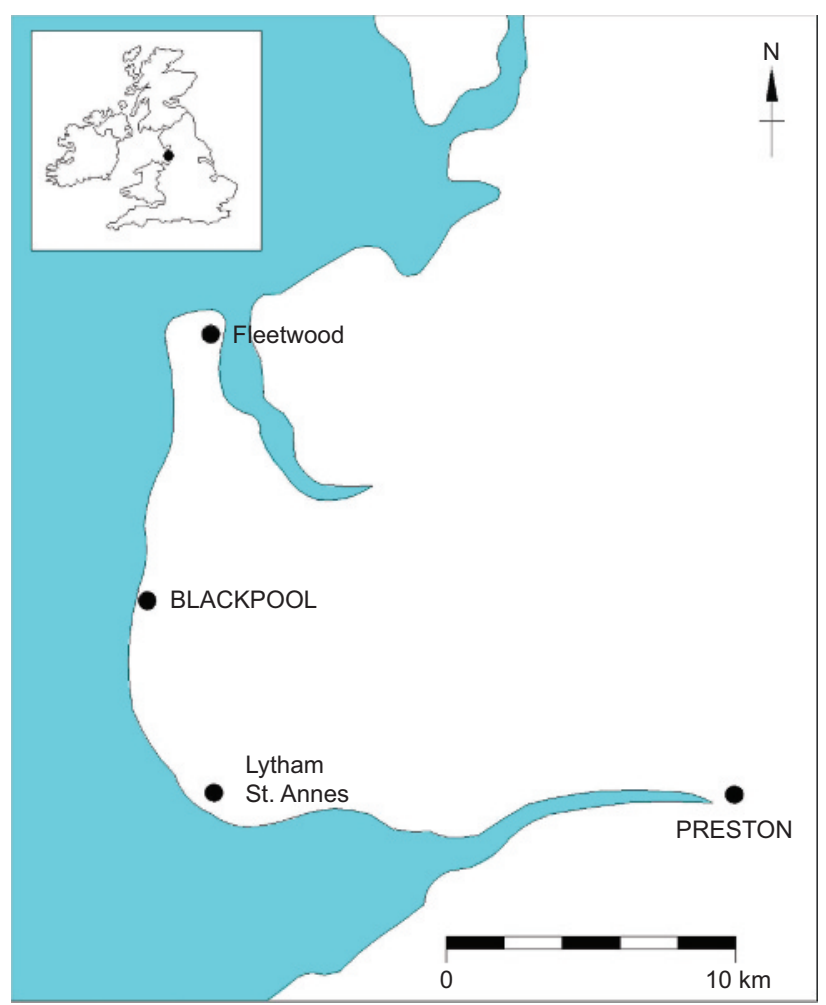

Figure 1. Location map

(e) Constructing the scheme in the coastal environment, maintaining high-quality standards while reducing risk and improving efficiency.

\section{Background}

Blackpool can trace it origins as a mass-tourist destination to the industrial revolution. Development of the railway network in the mid-nineteenth century enabled workers from industrial towns and cities across the country to visit the coast and Blackpool's growth quickly followed.

Reflective of the town's exponential development, at least three different coastal defences were constructed in the central section during the nineteenth and early twentieth centuries. Prior to construction of the first defences, the natural shoreline consisted predominantly of boulder clay cliffs and was eroding at approximately $2 \mathrm{~m}$ per year (Banks, 1920).

At the time of project inception, the existing defences consisted of mass concrete walls (approximately $2 \mathrm{~m}$ thick) faced with columnar basalt. These defences had been constructed in phases from around 1900 in the south to around 1912 in the north. At the time of their construction the defences were considered state of the art and, given their longevity, the defences could be considered to have served the town well.

In recent years, age-related deterioration in association with increased overtopping events (Figure 2) had resulted in the need for new defence structures. In line with the recommendations of the Shoreline Strategy Plan updated in 2004 (Blackpool Borough Council/Halcrow Group Ltd, 2004, unpublished) Blackpool Council, with support from Halcrow Group Ltd, prepared a Project Appraisal Report (PAR; Blackpool Borough Council/Halcrow Group Ltd, 2004, unpublished) to appraise options for capital works to improve or replace the existing coastal defences.

The appraisal was undertaken in accordance with the UK Department for Environment, Food and Rural Affairs (Defra) project appraisal guidance (MAFF, 2001). This included consideration of a long list of potential options, including: do nothing; refurbish the existing defence and raise the crest level, new rock armour revetments, new stepped revetments with and without crest walls; offshore breakwaters and beach recharging.

The long list of options was reviewed against a series of criteria, to prepare a shortlist of options. The criteria included

(a) coastal defence performance

(b) safety during construction, use or maintenance

(c) amenity value with particular reference to tourism

(d) effect on the urban environment

(e) effect on the natural environment.

The preferred option was selected from the shortlist of options based upon an economic appraisal, in accordance with the

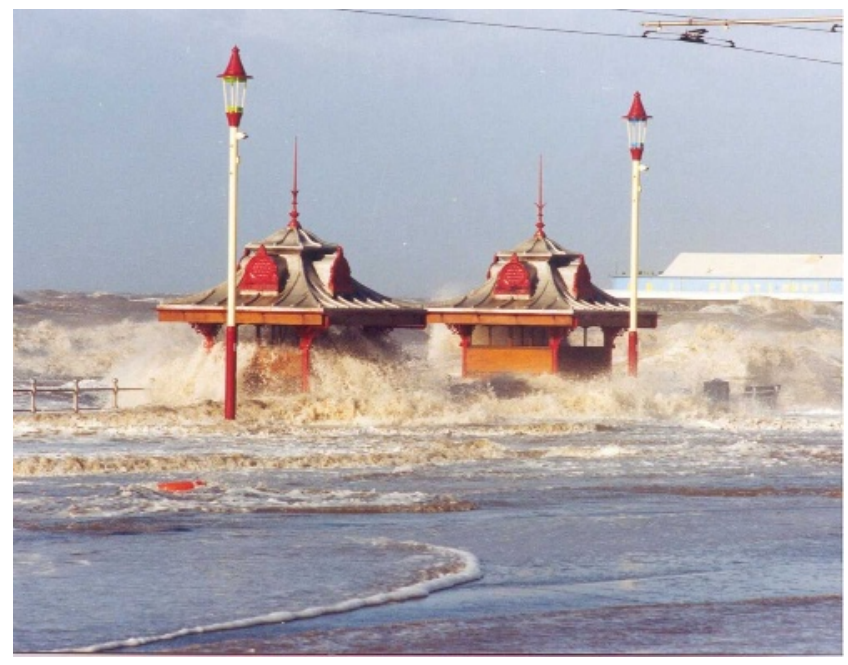

Figure 2. Overtopping of frontage prior to new works 
Defra guidance. The recommended scheme provides vital coast protection for 600 businesses and residences, including Blackpool's three historic piers, Blackpool Tower, the Tower Ballroom, the Winter Gardens, the Sea Life Centre and numerous amusement arcades, pubs, hotels and restaurants. The scheme also delivers flood protection improvements to 850 properties, and eliminates the regular flood events that currently result in closure of the adjacent road and tramway up to four times per year.

Following Defra approval of funding for the works, detailed design was undertaken in 2005 and construction works commenced on site in August 2005 with a 5-year programme.

Given the national cultural importance of the town, there was a high degree of public interest throughout the scheme. During the initial planning stages, public consultations were undertaken to ensure the interests of the local businesses, the residential community, and visitors were addressed. Consultations identified that residents and visitors valued the sea views and beach accessibility from the promenade. This further reinforced these elements as important design criteria.

During the construction stages, public interest in the scheme was facilitated by the visitor centre. A large amount of positive visitor feedback was provided through this facility. A general degree of appreciation for the scheme was voiced during construction. This was aided by the fact that the problems associated with the old defences and promenade were highly apparent to the public. In addition, the project team endeavoured to maintain community interest in the scheme by undertaking visits to local schools and colleges and involving the regions' universities, resulting in many local students undertaking projects focusing on various aspects of the scheme.

\section{Developing a defence shape}

One of the principal attractions of Blackpool as a seaside resort is the relationship between the promenade and the beach. Blackpool has one of the longest continual promenades in the world (approximately $8 \mathrm{~km}$ in total) and the central section is renowned for its sea view and open vistas. Maintaining and enhancing this was therefore essential to achieve the aspirations of the Blackpool masterplan.

In order to develop a defence shape that achieved this, Blackpool Council, supported by Halcrow, contracted ABP Marine Environmental Research (ABPmer) to conduct physical and numerical modelling to assess the performance of the existing defences, the performance of proposed alternative defence forms, and to optimise the defence shapes (ABPmer, 2004). This work involved three distinct studies. (a) Two-dimensional (2D) physical modelling. This achieved an understanding of the performance of the defences in terms of overtopping and beach scour at the toe.

(b) Three-dimensional (3D) physical modelling. This looked at the effect on changes to the plan shape of the new defence.

(c) Numerical modelling. This considered the effect on the wider frontage of the potential changes to the defence structures.

The 2D modelling focused on delivering the improved resistance to overtopping with minimal effect on the sea view. This work looked at 17 different initial defence types covering three distinct sections of the defence. The preferred option was selected based upon defence performance, measured in terms of overtopping and scour, and by review of the potential appearance and visual impact of the new defence with input from the landscape architect. The selected option has a one-inthree stepped revetment with steps approximately $150 \mathrm{~mm}$ high.

Optimisation of the selected option introduced a mini-berm between the stepped revetment and the primary defence wall together with a secondary wall set back behind the primary defence to contain overtopping of the primary defence. The mini-berm was a novel introduction, which allowed a small reduction in primary defence height with no effect on wave overtopping. This is principally due to greater energy dissipation over the width of the crest, similar to improvements shown for increased crest widths of rock-armoured structures (Besley, 1999).

The final optimised defence shape included a $5 \mathrm{~m}$ wide miniberm, a primary defence crest level of $+7 \mathrm{~m}$ Ordnance Datum Newlyn (ODN), which is approximately $500 \mathrm{~mm}$ above the lowest section of existing defence. This compares to mean high water spring tide level of $+4 \cdot 0 \mathrm{~m} \mathrm{ODN}$, and existing beach levels that vary between $3.0 \mathrm{~m} \mathrm{ODN}$ in the south to $1.0 \mathrm{~m}$ ODN in the north. The $750 \mathrm{~mm}$ high secondary wall set $17 \mathrm{~m}$ behind the primary defence contains water that overtops the front wall and allows it to drain back to the sea. Figure 3 shows the optimised defence shape.

In the northern part of the works the topography of the land gradually rises up to $4.5 \mathrm{~m}$ above the required primary defence height. In this area the minimisation of primary defence height to protect the view was not required. The selected defence shape in this area incorporated the same stepped revetment profile with mini-berm at $5 \mathrm{~m}$. This shape delivered enhanced scour performance, critical to the stability of the defence. The wave walls were sloped in elevation to follow the constant gradient of the promenade, eventually peaking at a height of $6 \mathrm{~m}$ above the berm. Where the primary wall rose above 


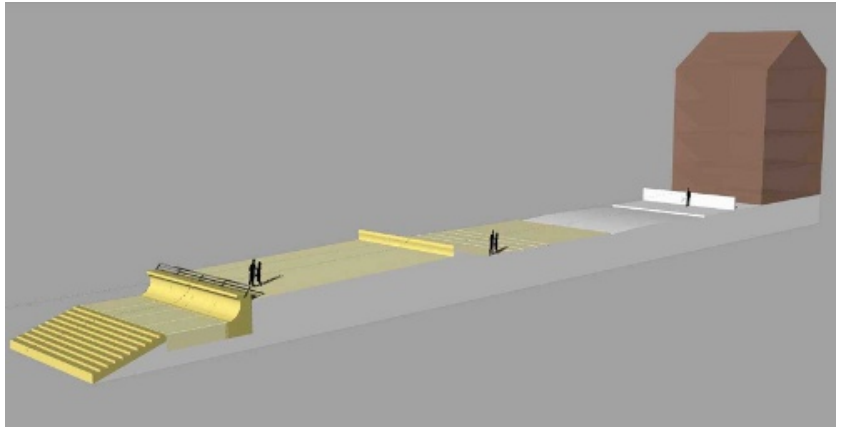

Figure 3. Optimised defence shape

$+7 \cdot 5 \mathrm{~m} \mathrm{ODN}$, the need for the secondary flood wall was eliminated.

The works were constructed in front of the existing defence line, encroaching onto the foreshore. The effect of the encroachment, and the changes to the alignment of the defences including the creation of enlarged headland features on the coastal processes were tested through $3 \mathrm{D}$ physical modelling and through numerical modelling of the wider area. The effects on wider coastal processes were seen in the modelling to be minimal.

\section{Reconnecting the town to its beach}

The existing defences take the form of vertical basalt-faced walls with occasional access provided in the form of steep steps and vehicle ramps (Figure 4). This is both undesirable and inaccessible to the vast majority of visitors to the sea front. The shape of the existing defences was considered as a physical and

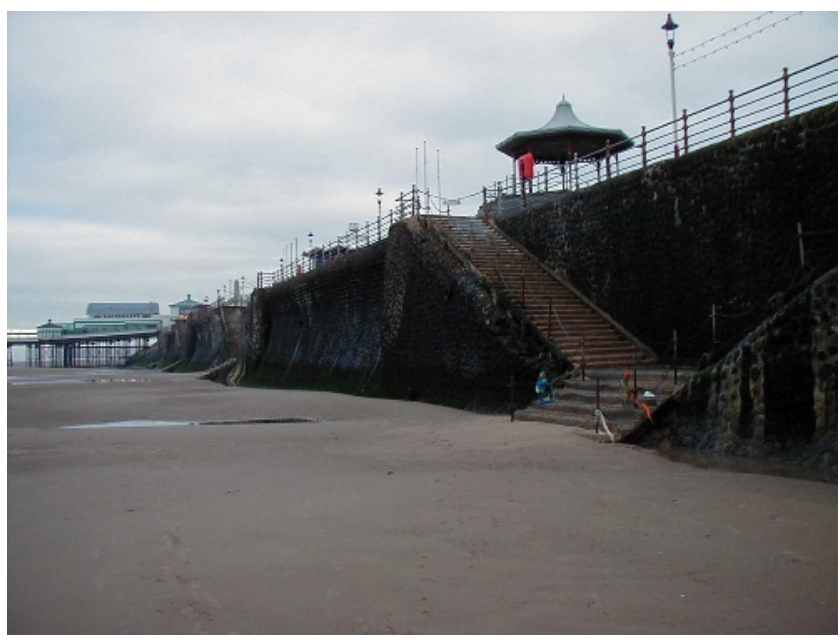

Figure 4. Existing defences form a visual and physical barrier to the beach visual barrier between the beach and the town. Removing this barrier was a key opportunity identified through the Blackpool Masterplan to 'reconnect the town to the beach'.

The verticality of the defence has been changed through the introduction of the one-in-three stepped revetment with a shorter recurved wave wall and mini-berm. By dividing the defence into multiple elements the visual effect of the height is broken into a series of smaller layers which significantly improves beach access.

The plan shape of the defences incorporates five curved headlands. The headlands were created to provide improved public spaces and landscaping opportunities. The shape of the headlands and their spacing aims to break the regular linearity of the standard defences. Three-dimensional physical modelling and numerical modelling showed that the selected shape has no significant effect on the wider sediment transport regime, but the headlands have encouraged accretion between them providing small areas of high water beach.

In architectural terms, the defences are conceptualised as dunes, providing a visual link to the natural dunes south of Blackpool, a notion conveyed visually by colour and geometry. This conceptualisation extends landward onto the promenade and set-back wall. The revetment and wave wall has been constructed using a pigmented concrete developed specifically for the scheme to resemble the colour of sand on the Blackpool beach. The size of the project and the volume of material involved meant that the production of a bespoke pigment was economic, and the use of local batching facilities for both the production of the precast and the in situ concrete elements ensured continuity of material colour and shade throughout the works.

Access to the beach through the old defences was provided through sets of access steps and ramps. Due to the high reflectivity of the old sea wall, there were ongoing problems with scour at the base of the access steps. These problems presented a significant health and safety issue, causing members of the public to become stranded on the foreshore between access points, sometimes requiring rescue. The stepped revetment shape allows access and egress from the beach along the full length of the scheme onto the berm area which provides continual longitudinal access along the frontage between access steps through the wave wall.

New ramps have been provided between each headland allowing vehicle access to the beach along each discrete section. A specific access was designed in consultation with the local Royal National Lifeboat Institution for the launch 
and recovery of their boats with a multi-directional ramp that allows for easy launch into the prevailing wind.

\section{Linking the new sea front to public realm}

This coastal defence project presented an opportunity to catalyse regeneration of the town by focusing on the sea front tourist area. Additional grants, and Blackpool Council's own funds have been added to the Defra grant to assist in the delivery of high-quality public realm which is fully integrated with coastal defence requirements. This upgrade and significant revitalisation to the Blackpool central area aims to enhance the town's image and consolidate its reputation as the UK's premier coastal resort.

The five new headlands are a demonstration of the strategic use of these funds. It is intended that each headland will become the focal point for a particular activity or theme, and will form a series of new attractions to enhance the visitor experience of the town. The centrepiece of the themed headlands will be the Tower Festival Headland directly opposite the iconic Blackpool Tower. This headland will accommodate tourist facilities including a feature wedding chapel, provision for outdoor events and landmark art works.

The design of the public realm has been assimilated with the coastal defence elements through continuity of scheme elements together with the provision of specific connecting features. The most significant elements are listed here.

(a) Continuity of the scheme's aesthetic and durability through the design of all promenade elements; this can be seen in features such as the elliptical-shaped in situ concrete substation building, precast signage and items of street furniture such as stainless steel lifebuoy housings and bins.

(b) Precast statue plinths positioned within the wave wall returns underline the objective to create high quality and distinctive public realm. These feature elements flank the entrance steps in various locations and are designed to accommodate demountable statues of up to $7 \cdot 5 \mathrm{t}$ mass and the associated incident wave loading. These features provide a striking visual connection between the public realm area and the coastal defences.

(c) The design of the rear flood wall has been developed to provide alternative features in addition to the primary flood defence requirement. The complex geometric opportunities afforded by precast concrete allowed integral seating forms to be created providing rest areas on the western side of the wall.

(d) The landward side of the rear flood wall has been utilised to create shelter for planting. This shelter zone in combination with use of salt-tolerant species has enabled large swathes of the eastern promenade to have greenery and soft landscaping (Figure 5). These areas have proved extremely popular with visitors as previously the central area promenade was devoid of soft landscaping.

\section{Improving durability of materials}

A specific requirement of Blackpool Council was to ensure the scheme delivered an improved new coastal environment, which would remain an attractive frontage throughout its 100 -year design life.

It was important that the scheme was sustainable and resource efficient in addition to being cost-effective to maintain, thus ensuring best-value whole-life cost over its design life. This meant that extreme sea levels and wave conditions comensurate with the 100-year design life had to be accommodated. Furthermore, an enhanced level of durability over and above normal practice was incorporated. The design focused on the following items.

(a) Elimination of steel reinforcement where structurally possible.

(b) Where steel reinforcement was required, enhanced reinforcement (e.g. stainless steel) was adopted in exposed areas.

(c) Improved structural forms.

(d) Improved reinforcement detailing.

(e) Improved construction quality.

At an early stage in the project development, a decision was taken to maximise the use of offsite precast elements in construction. This approach enabled improved construction quality due to greater control of the working environment; it also facilitated detailed quality control and rigorous checking of the works. The prefabrication process reduced the risk of damage through actions associated with the marine environment had it been constructed in situ.

The stepped revetment is formed as a series of precast slabs. It is located within the intertidal and splash zones and therefore is

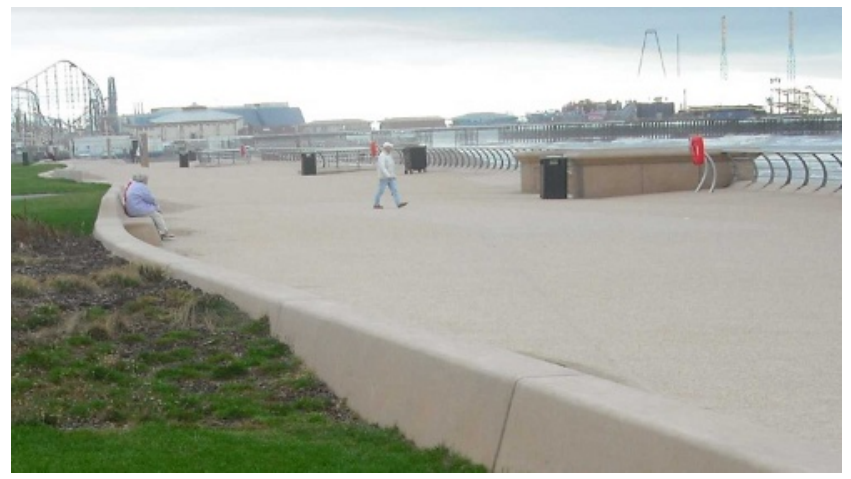

Figure 5. Rear flood wall used as seating and landscaping feature 
within the most onerous area for reinforcement corrosion as defined by clause 58.3.3.2 of BS 6349 Part 1 (BSI, 2000). The potential to avoid the use of traditional reinforcement measures was identified early on. In their permanent condition the stresses on the slab units would be low and therefore the provision of reinforcing steel was being driven by the lifting of the units.

Following development of the lifting process, the detailed design adopted the use of a synthetic polymer macro-fibre in place of the traditional reinforcing steel which still provided post-crack strength to the structure. The omission of the reinforcement delivered a more efficient design, avoiding the costs associated with reinforcement fixing and ensured the revetment is immune to the effects of chloride ingress and subsequent reinforcement corrosion. This was the first time such fibre reinforcement had been used in the UK on this scale (Perry, 2006).

The wave wall is also within the splash zone and is therefore highly susceptible to chloride ingress and reinforcement corrosion. The stresses that are a result of wave attack on the structure mean that the use of steel reinforcement could not be avoided. In order to ensure durability, stainless steel reinforcement on the exposed face was adopted. Normal carbon steel reinforcement was utilised on the buried rear and bottom faces which helped to mitigate the costs associated with stainless steel.

The secondary flood wall which stretches over approximately $2 \mathrm{~km}$ of the frontage is subject to similar environmental agents, and stresses which require appropriate reinforcement. In addition to providing the necessary flood protection, the wall forms a key architectural feature on the new promenade. Like the wave wall it was originally intended to use stainless steel in the rear flood wall. By the time detailed design of the rear flood wall commenced, the cost of stainless steel had become prohibitively expensive due to market fluctuations. As a cost-effective alternative, the use of a novel polymer composite reinforcement (glass-fibrereinforced plastic, GFRP) in the rear flood wall ensured optimum durability in this critical element. Again, this was the first time such a product was used on this scale in the UK (Cunningham et al., 2008).

Detailing and selection of shapes is critical to the durability of structures. Specific areas of focus are generally those areas where chlorides can build up, leading to acceleration of the onset of corrosion, or areas where chloride attack can occur from multiple faces. The design focused on eliminating these issues through the following actions.

(a) Selection of a concrete mix that included slag cement replacement (CEM IIIA). This has improved resistance to chlorides and sulfates in seawater and reduces the effects of early thermal movements and associated cracking.

(b) Ensuring appropriate drainage by providing suitable crossfalls across the berm slab to allow rapid run-off of water.

(c) Including additional surface cover to the reinforcement.

(d) Avoidance of corners and abrupt changes in direction on all concrete units.

(e) Casting of precast units face down, such that the surface to be exposed in the finished works is cast at the bottom of the mould. This ensures a high-quality surface finish and increases the surface density of the concrete, improving resistance to the ingress of chlorides and sulfates.

The above areas of focus were selected based upon guidance available at the time of the design including the British Standard for Maritime Structures (BSI, 2000), and specific reference texts on the use of concrete in coastal structures (Allen, 1998).

The architectural design demanded a high aesthetic on all secondary features on the promenade. One key element was the hand-railing on top of the wave wall. Aluminium alloy was adopted to provide the most cost-effective durable structure while delivering the structural performance and geometric form required. Elsewhere, Duplex stainless steel was adopted for the safety signage and lifebuoy support structures.

\section{Constructing the scheme}

Blackpool Council recognised the challenges of delivering the project at an early stage and considered that early contractor involvement (ECI) would bring about benefits in terms of maximising buildability of the works and therefore improving the quality of the finished product while reducing the construction costs (Hill et al., 2005).

The project team worked in partnership to deliver the best quality product in tandem with the most practical solutions posible. The number of innovations adopted on the project was a direct result of the partnership approach between designers and the contractor. At design stage and during construction regular value engineering exercises fostered by the partnering environment helped to drive optmisation (Cunningham and Pomfret, 2007).

There are a number of areas in which the ECI process delivered significant improvements to the design. The following highlights some of the ways in which the partnership developed the design to enhance its constructability. 
(a) In order to optimise productivity in the tidal window, reduce the risk associated with the coastal environment and ensure quality commensurate with the client's brief, the design of the revetment and wave wall maximised the use of offsite precast units, removing the work from the high-risk zone and maximising productivity away from tidal restrictions.

(b) The revetment design utilised a sandwich construction, the lower part was formed as a thick blinding layer applied to the formed slope of the revetment. The thick blinding layer provided resistance to the effects of waves and tides during the construction period, but the temporary nature meant that surface damage due to the effects of wave attack on the immature concrete surface were not critical. This improved productivity by divorcing the works to form the slope and the works to provide the finished high-quality surface.

(c) The amount of precast elements meant that the most economic solution was to cast in reusable steel moulds. The geometry of the precast elements was rationalised in order to minimise the number of moulds required, and simplify the shape of the moulds. The use of adjustable moulds further contributed to efficiencies.

(d) Unit sizes were derived from the stability in the permanent case in tandem with the available crane capacities on site and in the precast yard, and the desire to maximise the use of mould shapes. The weight of the underlying blinding was accommodated in the design ensuring efficiency of the construction by keeping the weight of the precast units as low as possible.

(e) The complete construction cycle was considered in the design works through production of an agreed methodology for undertaking the works. This took the precast units from casting, striking, lifting, turning, storing, transportation and installation. By doing this, and accounting for the anticipated concrete strength at each stage, an efficient use of materials such as the polymer fibre reinforcement could be made. The agreed methodology included appropriate checks on strength, etc. prior to each key lifting operation.

(f) Innovative vacuum lifting equipment was developed during the design phase and used to eliminate the need for cast-in anchors on the revetment units and improve productivity and control of the lifting operations. The operation of the unit is shown in Figure 6. The technique also provided improved efficiency of the placing operation, enhancing site productivity in the restricted tidal working area. This was the first time such a technique had been adopted on this scale in a coastal application and the

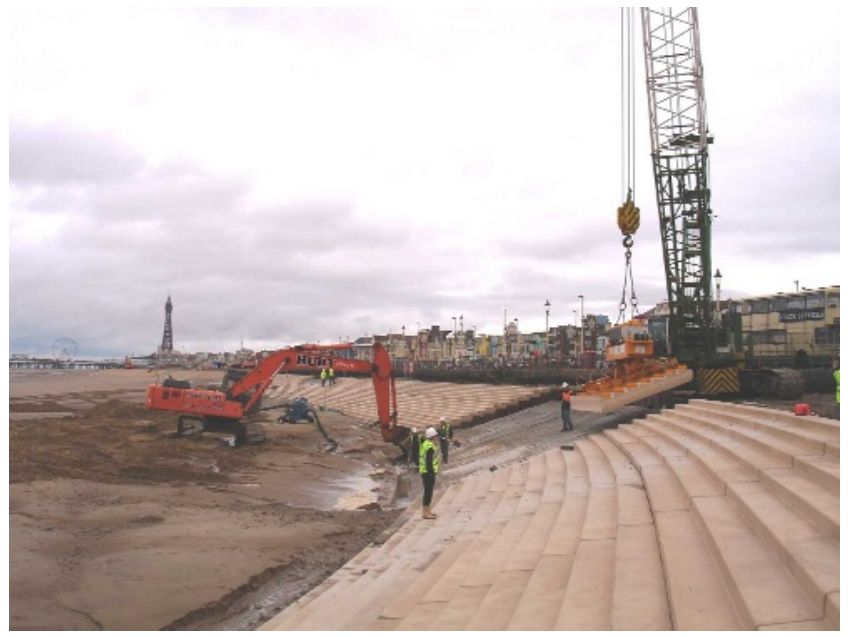

Figure 6. Vacuum lifting of revetment units improved efficiency and avoided the use of cast-in lifting anchors

technique has since been adopted at other sites around the UK.

(g) Given the numbers of precast elements involved in the project ( $\sim 40000$ units), it was economic to set up a dedicated precast factory. The benefits were multiplied by partnering with another coastal defence project at Cleveleys to the north of Blackpool which was on site during the early stages of the central area project. The factory was set up at Thornton (approximately 7 miles from the project site). Units were produced and stored so that the site could operate on a just-in-time basis, namely units being delivered when they are ready to be placed. This allowed storage areas on site to be kept to a minimum, an important factor when considering both the construction programme and also the tourism and business interface.

The partnering approach also provided improvements to sustainable employment by provision of a facility with a potential future use, and through investment in skills and training for the local workforce. Where possible, effort was also made to employ local labour and provide training as necessary. This allowed a vital skills base to be generated within the area. It is estimated that up to 120 local jobs were created as a direct result of the scheme.

Construction commenced on site in September 2005, with major completion taking place by August 2010. The coastal defence elements were constructed on programme, an achievement aided by the efficiencies accrued from the collaborative design approach. 
The success of the scheme, and the partnering approach to the design and construction process was highlighted through features in industry press (McKenna, 2006), and through a case study in recent Ciria guidance on the use of concrete in the maritime environment (Ciria, 2010). Initial feedback and reaction to the scheme by local businesses, stakeholders and the general public has been very positive.

\section{Conclusions}

The completed central area coast protection scheme provides Blackpool with a unique, creative and innovative sea front to be enjoyed by generations to come (Figure 7). The project sought to upgrade existing coastal defences, to protect the town from flooding, to improve the relationship between the town and its beach, to deliver high-quality public realm and to enhance accessibility along the promenade. It has successfully achieved these aims.

The selected defence shape maintains the valued sea views and provides a much improved setting for the iconic attractions of the sea front. Following completion of the works, the defences have eliminated flooding associated with high-frequency storm events which previously impacted upon local transport and tourist infrastructure. Initial figures for 2011 indicate an upward trend in visitor numbers compared with 2010 and significantly above pre-construction (2005) levels.

The project team worked in partnership to deliver innovative solutions that provided quantifiable benefits in terms of aesthetic quality, durability and constructability. A number of the solutions adopted on the central area project have been

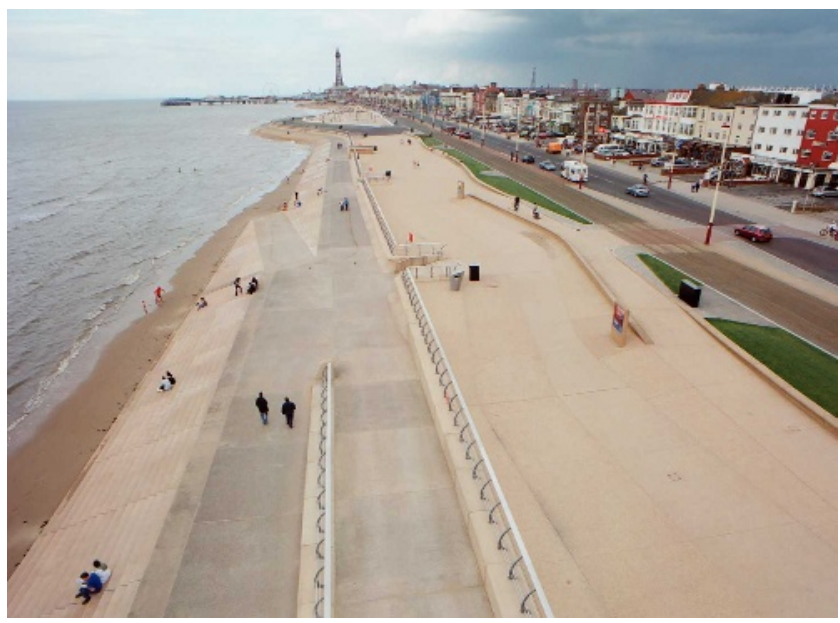

Figure 7. Completed scheme forms key part of world-class visitor experience (courtesy Birse Coastal) used in other schemes around the UK and elsewhere, delivering a legacy benefit greater than originally anticipated.

A high level of public interest in the scheme fostered through public engagement in the development stage was maintained through the construction phase, and positive feedback on the works was continually received through a public information centre.

The success of the scheme should principally be considered as providing essential coastal and flood protection for the town and its tourist facilities and to continue this with anticipated climate change effects. However, it should also be considered a resounding success for its multi-functional approach in delivering coastal defence infrastructure that provides new public spaces, high-quality public realm, landscaping and artistic opportunities in parallel to reaffirming Blackpool's position as the UK's most popular coastal resort.

\section{Project team}

Engineering Design: Blackpool Council and Halcrow Group Ltd.

Landscape Architecture: EDAW and LDA Design.

Project Management and Site Supervision: Blackpool Council.

Principal Contractor: Birse Coastal.

Precast Subcontractor: SLP Pre-cast.

\section{Acknowledgements}

The project was funded by the following parties: Blackpool Council; Defra; Environment Agency; European Regional Development Fund (ERDF); North West Regional Development Agency (NWDA).

\section{REFERENCES}

ABPmer (2004) Blackpool Central Area Coastal Protection. Physical and Numerical Model Testing. ABPmer, Southampton, UK, R. 1064.

Allen RTL (1998) Concrete in Coastal Structures. Thomas Telford, London, UK.

Banks H (1920) Blackpool sea coast defence works. Transactions of the Society of Engineers, 6 December. Besley P (1999) Overtopping of Seawalls - Design and Assessment Manual. Environment Agency, Bristol, UK, R\&D Technical Report W178.

BSI (2000) BS 6349: Part 1: Maritime structures, code of practice for general criteria. BSI, Milton Keynes, UK. Ciria (Construction Industry Research and Information 
Association) (2010) C674: The use of concrete in maritime engineering - a good practice guide. CIRIA, London, UK. Cunningham LS and Pomfret ML (2007) Partnering contracts in practice at Blackpool, UK. Proceedings of the Institution of Civil Engineers - Municipal Engineer 160(1): 17-21.

Cunningham L, Burgess A and Spitz C (2008) Composite reinforcement for coastal defence project. Concrete 42(4): 22-24.

EDAW and Jerde (2003) Blackpool Masterplan. Blackpool Council, Blackpool, UK. See http://www.blackpool.gov. uk/Services/M-R/Masterplan/Publications/ (accessed 24/01/ 2012).
Hill A, Robertshaw G, Emmitt C and Smith T (2005) Blackpool Central Area Coast Protection Scheme. In Proceedings of the International Conference on Coastlines, Structures and Breakwaters (Allsop NWH (ed.)). Thomas Telford, London, UK, pp. 307-319.

MAFF (Ministry for Agriculture, Fisheries and Food) (2001) FCDPAG1, Flood and Coastal Defence Project Appraisal Overview. MAFF (now Defra), London, UK.

McKenna J (2006) Defender of the lights. New Civil Engineer, New Concrete Engineer Supplement, September, pp. 1012.

Perry B (2006) An innovative solution for sea defence renewal. The Structural Engineer 84(23): 18-19.

\section{WHAT DO YOU THINK?}

To discuss this paper, please email up to 500 words to the editor at journals@ice.org.uk. Your contribution will be forwarded to the author(s) for a reply and, if considered appropriate by the editorial panel, will be published as discussion in a future issue of the journal.

Proceedings journals rely entirely on contributions sent in by civil engineering professionals, academics and students. Papers should be 2000-5000 words long (briefing papers should be 1000-2000 words long), with adequate illustrations and references. You can submit your paper online via www.icevirtuallibrary.com/content/journals, where you will also find detailed author guidelines. 